of his system and without considering the essence and foundations of ethics of education and training, defining them as relevant and timely only for the educational system of the last century.

Key words: Ivan Franko, creative heritage, higher education, pedagogy, education.

Дата надходження статті: 27.04.2021 p.

Рецензент: доктор педагогічних наук, професор Білавич Г. В.

УДК 37.091.113:378.046-021.68(477)

DOI https://doi.org/10.37915/pa.vi49.283

Вишневська Я. А. ,

orcid.org/0000-0003-3703-4119

\title{
РЕТРОСПЕКТИВНИЙ АНАЛІЗ ІСТОРИКО-ПЕДАГОГІЧНИХ ПЕРЕДУМОВ РОЗВИТКУ ПІСЛЯДИПЛОМНОЇ ОСВІТИ КЕРІВНИХ ПЕДАГОГІЧНИХ КАДРІВ УКРАЇНИ
}

У статті досліджено історико-педагогічні передумови становлення системи післядипломної освіти керівників закладів освіти у період першої половини ХХ сторіччя. У контексті послідовних перетворень у системі післядипломної педагогічної освіти розкрито особливості історичного періоду периої половини ХХсторіччя, в якому відбувалось формування національної системи післядипломної педагогічної освіти, зокрема зароджувались процеси, пов'язані з підвищення квахіфікації керівних педагогічних кадрів. Обьрунтовано, що процес розвитку післядипломної освіти керівних педагогічних кадрів нерозривно пов' язаний iз розвитком всієї системи післядипломної педагогічної освіти та є наслідком історичного усвідомлення важливості ролі ефективного управління закладом освіти у підвищенні якості освітнво-виховного процесу. На прикладі переписів працівників освіти, що проводились у 1929-1933 роках, надано характеристику кількісному та якісному складу педагогічних працівників, у тому числі наведено рівень професійної підготовки керівних педагогічних кадрів до управління закладами освіти. Охарактеризовані основні форми підвищення кваліфікації педагогічних кадрів у першій половині ХХ сторіччя, серед яких як таку, що мала особливе значення для професійний розвитку керівників шкіл, виокремлено заочну педагогічну освіту, зописом напрямів за якими здійснювалась підготовка. Зроблено висновок, що питання необхідності у запровадженні ефективного управління закладом освіти виникло як реакція на поступові політичні, соціальні та культурні зміни в украйнському суспільстві та державі, що поглиблювали проблеми розвитку всієї освітньої галузі. А наукове переосмислення в середині ХХ сторіччя провідної ролі ефективного управління закладом освіти та професіоналізму керівника стає передумовою виокремлення із загальної системи післядипломної педагогічної освіти важливої ї̈ підсистеми, що мала на меті постійне професійне зростання керівних педагогічних кадрів.

Ключові слова: курси підвищення квалібікації, керівні й педагогічні кадри, програма курсів, форма і зміст.

Постановка проблеми. Перебудова системи загальної середньої освіти України вимагає пошуку нових шляхів адміністрування роботи закладів загальної середньої освіти, від ефективності якого залежить надання якісної сучасної освіти.

Досягнення визначених реформою «Нової української школи» цілей неможливе без забезпечення закладів загальної середньої освіти професійно підготовленими, ініціативними, прогресивними керівниками, здатними до запровадження змін. Зазначене закономірно зумовлюе потребу в розвитку професійних компетентностей, необхідних керівнику для організації ефективного управління закладом освіти.

*C) Вишневська Я. А.

U3 
У цьому напрямку післядипломній педагогічній освіті відводиться провідна родь у професійному розвитку керівників закладів загальної середньої освіти. Ії завданням є підготовка таких управлінців, які будуть здатні забезпечити визначений державою курс на реформування системи освіти в Україні.

Осмислення та усвідомлення передісторіїі післядипломної освіти керівників закладів загальної середньої освіти доцільно здійснювати крізь призму історичних подій, становлення та розвитку всієї післядипломної педагогічної освіти України.

Аналіз досліджень. В останні десятиліття до питань удосконалення професійних якостей педагогічних працівників у післядипломній освіті прикута увага багатьох науковців. Особливості історичного розвитку післядипломної освіти педагогічних кадрів досліджувались Г. Біляніним, С. Крисюком, А. Кузьмінським, В. Олійником, П. Худомінським. Дослідниками Є. Голобородько, А. Зубком, Н. Клокар, Н. Чепурною вивчалися теоретико-метододогічні засади системи післядипломної освіти педагогів. Питання професійного розвитку вчителів були предметами досліджень І. Жорової, В. Примакової. Науковці Л. Король, В. Кузьменко, Н. Слюсаренко, О. Сухомлинська, В. Шарко, І. Якухно аналізували питання генези національної післядипломної освіти педагогічних працівників.

Однак проведені дослідження не охоплюють всіх питань становлення та розвитку такої невід'ємної складової системи післядипломної педагогічної освіти України, як післядипломна освіта керівників закладів загальної середньої освіти, що актуалізує проведення комплексного аналізу передумов її виникнення.

Мета статті - дослідження передумов становлення післядипломної освіти керівних педагогічних кадрів.

Викдад основного матеріалу. В реаліях сьогодення розвиток будь-якої системи пов'язують не лише 3 постійним ії вдосконаленням, а й збереженням стабільності та функціональності. Зрозуміло, що утворенню системи передуе період створення певних умов і виникнення окремих іiі складових з поступовим зміцненням зав' язків між ними.

Розвиток системи післядипломної освіти керівних педагогічних кадрів не можна розгдядати поза контекстом становлення і розвитку всієї системи післядипломної освіти педагогічних працівників. Саме в іiі надрах зародилася та набула розвитку їі важлива підсистема, що покликана забезпечувати зростання професіоналізму та розвиток професійних компетентностей освітніх управлінців.

Історично склалось, що вдосконалення професійної майстерності педагогічних працівників в Україні бере свої витоки з імперської Росії.

Зазначимо, шо аналіз архівних матеріалів та наукових праць учених засвідчив, що поряд зі спробами запровадження в XIX - на початку XX століття перших організаційних форм підвищення кваліфікації вчителів спостерігається зростання уваги до осмислення стану та змістового аспекту проблеми управління закладом освіти, ролі та значення особистісних та професійних якостей його управлінців у організації освітнього процесу. В цей період організовуються та проводяться різні форми професійного розвитку педагогів: конференції та з'ізди вчителів, 4-6 тижневі курси, на які запрошуються різні категорії педагогічних працівників, зокрема директори та інспектори шкіл.

Доволі цікавим є період з 1917 по 1919 роки, який був охарактеризований в історичних джерелах як період української революції. Цей період був перенасичений політичними, суспільними та воєнними подіями. В Україні зміна влади відбувалась кожні 2-3 місяці, окрім Гетьманщини, коли влада в одних руках була сконцентрована майже 6 місяців. Такі політичні події вплинули й на розвиток системи освіти України, зокрема на процеси професійного розвитку педагогічних працівників. Незважаючи на те, що освіта на теренах України розвивалась за суміжною траєкторією з російською 
освітньою галуззю, у вказаний період вона отримала відмінний від Росії вектор та здебільшого була націлена на українізацію національної освітньої галузі.

Сучасник подій, що відбувались у період української революції 1917-1919 років, С. Постернак, описуючи у своїх наукових працях зміни в освіті, зазначає, що кожен уряд, у чиїх руках перебувала влада в Україні, розуміючи необхідність українізації школи, намагався запровадити заходи, пов'язані насамперед із вивчення українознавства старими вчителями, та підготовку в цьому напрямку нового покоління педагогів. Так, за наведеними науковцем даними, влітку 1918 року було утворено 64 (59 українських та 5 польських і єврейських) курсів 3 українознавства для вчителів початкових, середніх і вищих шкіл. До програм курсів, поряд 3 дисциплінами українознавства та української мови, також вкдючались лекції про Єдину трудову школу. В період 1917-1918 років на запроваджених курсах перебувало майже все народне учительство України. Щорічні літні курси планувалося проводити на постійній основі із запровадженням викладання педагогічних та психологічних дисциплін [7].

Проте, часті зміни урядів у революційний період перешкоджали якісному здійсненню освітніх реформ в Україні. Однак, незважаючи на це, стає зрозумілим, що існуюча на той час система підготовки та підвищення кваліфікації педагогічних працівників не відповідала вимогам українського суспільства.

Таким чином, на підставі історичних джеред можна зробити висновок, що до початку 20-х років XX сторіччя на теренах України широко використовувалися різні організаційні форми підвищення кваліфікації педагогів, до яких залучалися різні категорії педагогічних працівників, а революційний період в історії України ще більше загострив та актуалізував проблему вдосконалення підготовки педагогічних кадрів відповідно до розвитку освітньої системи. Проте, багато реформ щодо професійного розвитку педагогів України та підготовки їх до роботи в нових реаліях не буди реалізовані.

Окремі складові існуючої на сьогодні система підвищення кваліфікації керівних педагогічних кадрів почали з'явдятись у перші роки становдення радянської вдади у 1920-1930 роках XX сторіччя. Цей період характеризується як посиленням уваги влади до питань підвищення кваліфікації педагогів, так і їі ідейно-політичним забарвленням, а також збільшенням репресивного тиску, в тому числі й на українських учителів. Поряд із реформами освіти, які здійснювалися відповідно до Положення «Про єдину трудову школу УРСР» 1919 року, важливого значення надавали й питанням підвищення кваліфікації освітян, що, на нашу думку, було пов'язано з розумінням партійним керівництвом провідної ролі працівників освіти у впливі на ідейно-політичні погляди населення.

А тому в існуючу систему освіти вносились вагомі зміни, які безпосередньо стосувалися підвищення квадіфікації педагогів. Декретом від 18 лютого 1921 року «Про навчальну повинність працівників соціального виховання Ради Народних Комісарів УРСР» було зобов'язано всіх працівників народної освіти до 40-річного віку пройти перепідготовку на спеціальних шестимісячних курсах для засвоєння обов'язкового мінімуму й політичної грамоти, що завершувалися перевіркою набутих політичних знань $[10$, с. 9].

За твердженням В. Крисюка, запроваджені в цей період курси підвищення кваліфікації працівників освіти мали безсистемний характер та проводились без врахування принципу наступності щодо професійного розвитку, що значно знижувало їхню ефективність [2, с. 14].

Суттеві зміни також торкнулися і системи організації управління освітою. Як зазначає С. Сірополко, з 1917 року було скасовано систему інспектування закладів освіти, а управління освітою передано органам місцевого самоврядування. Згодом інститут інспекторів було все ж відновлено, а його основним завданням поставлено 
слідкувати за політичною благонадійністю вчителів. Відповідно до інспекторів у першу чергу ставились вимоги щодо їхнього комуністичного світогляду, а лише потім до освітнього рівня та педагогічного стажу. За задумами радянської вдади інспектори мали виконувати функції інструкторів працівників освіти, допомагати їм в організації, налагодженні та удосконаленні освітнього процесу [9, с. 780-781].

Розгортання мережі закладів освіти сприяло збільшенню чисельності педагогічних кадрів. Так, за даними, що наводить С. Крисюк, у період 1929-1933 років потреба республіки у педагогічних кадрах становила 83 тис. осіб, при цьому педагогічні заклади могли підготувати лише 29 тис. працівників [3, с. 121-122]. Такий дефіцит учителів компенсувався допуском до педагогічної роботи працівників 3 короткотривалою підготовкою, більшість 3 яких не мали вищої освіти. В цьому аспекті однією з важдивих форм підвищення кваліфікації педагогічних кадрів у 20-30-х роках стала заочна педагогічна освіта.

Вищезазначені процеси стосувалися й такої категорії педагогічних працівників, як керівники шкіл. $А$. Мельникова у своєму дослідженні наводить статистичні дані щодо рівня освіти педагогів за результатами перепису освітян, проведеного в 1933 році. Ці дані свідчать про вкрай низький рівень їхньої професійної підготовки. Зокрема, переважна більшість (70,5 \%) директорів шкіл мали середню освіту, вищу освіту здобули дише 13,5 \%, інша вагома частина директорів шкіл мали або неповну середню $(11,4$ \%), або лише початкову освіту (4,6 \%) [4, с. 15].

Ситуація 3 невідповідністю освітнього i професійного рівня педагогічних працівників, зокрема і керівних кадрів, потребувала невідкладного реагування. Проте, можливості для залучення педагогів до очних курсів були вкрай обмежені, перш за все, через відсутність на це коштів. Це значно актуалізувало значення заочної педагогічної освіти, зокрема і для професійного розвитку керівників.

У 1927 році засновано заочний педагогічний ЗВО при НКО УРСР, який у 1928 році було перейменовано на Всеукраїнський заочний інститут народної освіти. Основним завданням цього закладу було підвищення кваліфікації (докваліфікація) всіх учителів до рівня вищої педагогічної освіти [10, с. 11-12].

У 1930 році Всеукраїнський заочний інститут народної освіти було реорганізовано, а на його базі створено Всеукраїнський інститут підвищення квадіфікації педагогів. Навчання відбувалося за трьома напрямками: підвищення кваліфікації (докваліфікація) учителів; підвищення кваліфікації та перепідготовка; підготовка нових педагогічних кадрів освіти [3, с. 127].

Крім того, на інститут покладалось методичне керівництво перепідготовкою та підвищенням кваліфікації працівників освіти, яке полягало у розробці планів масової перепідготовки та підвищення фахової майстерності, підготовці навчальних матеріалів, допоміжної літератури, методичній допомозі освітянам [10, с. 11-12].

Наприкінці 30-х років XX сторіччя підвищення кваліфікації педагогічних працівників набуває своєї інституційності через утворення в 1939 році обласних та міських інститутів удосконалення вчителів. Ці заклади було створено відповідно до постанови № 86 від 5 дютого 1939 року «Про організацію в системі Наркомату освіти інститутів удосконалення вчителів» спочатку у Києві та Харкові. А через місяць згідно з прийнятою РНК УСРР Постановою № 956 від 17 березня 1939 року в інших областях України обласні методичні кабінети було реорганізовано та створено інститути удосконалення вчителів [6].

Отже, можна констатувати факт, що впродовж 20-30-х років XX сторіччя держава активно брала участь у розвитку післядипломної педагогічної освіти. Підвищення кваліфікацї, яке стало обов'язковою складовою професійної діяльності кожного педагога, здійснювалось із використанням таких форм: коротко та довгострокові курси як 3 відривом, так і без відриву від виробництва, стажування, семінари, педагогічні гуртки, конференції, наради тощо. Однак, слід відзначити, що підвищення кваліфікації 
такої категорії педагогічних кадрів, як керівники закладів освіти, здебільшого відбувалось в контексті післядипломної освіти вчителів та не мало власного вектору розвитку.

Однак, незважаючи на значну увагу 3 боку радянської влади та інституційне становлення системи післядипломної освіти педагогічних працівників, вона мала низку недоліків. Серед них: нерівномірне залучення до процесу підвищення кваліфікації різних категорій педагогічних кадрів, зокрема i керівних працівників; відсутність сформованих принципів та єдиних вимог до формування навчальних планів та програм.

Провівши аналіз історичних та наукових джерел, в яких висвітлювалися питання підвищення кваліфікації працівників освіти $[1 ; 2-4 ; 9 ; 10]$, зауважимо, що у період 20-30-х років ХХ сторіччя професійний розвиток педагогічних працівників, які виконували функції керівників шкільних установ, практично не виділяеться із загальної системи підвищення кваліфікації працівників освіти, a, отже, здійснювався без належного наукового підгрунтя щодо спрямування на покращення управління закладами освіти.

В. Гладуш, описуючи передісторію створення та розвитку Університету менеджменту освіти, зазначав, що перші намагання наукового підходу до питання підвищення кваліфікації педагогічних працівників були здійснені, починаючи з 1927 року, коли на базі Академії соціального виховання було створено Вечірній педагогічний інститут для підвищення кваліфікації працівників освіти, який вперше почав готувати і керівні кадри для освітньої галузі [1, с. 27].

3 розвитком системи шкільної освіти на початку $30-x$ років, значно загострюються питання, пов'язані 3 науковим розвитком та законодавчим врегулюванням системи організації ефективного управління школою. Так, у Постанові ЦК ВКП(б) 1931 р. «Про початкову та середню школу», окремий розділ було присвячено управлінню та керівництву школою, в якому зазначалося, що покращення якості роботи школи неможливе без рішучого підвищення якості управління школою з боку органів Наркомпроса, якнайшвидшого переходу до оперативного, конкретного і диференційованого керівництва [5, с. 160-161].

Постановою РНК СРСР и ЦК ВКП(б) від 1935 року«Про організацію навчальної роботи і внутрішній розпорядок в початковій, неповній середній і середній школі» було наголошено на посиленні керівництва школою, відповідальності вчителів за якість роботи і підвищення якості навчання. Відповідно до неї, директор школи ставав повноважним керівником, і на нього покладалась повна відповідальність за загальний порядок і результати роботи шкільного колективу [5].

Довоєнний період також характеризується різким зростанням уваги до проблем внутрішньошкільного управління. На той час припадає також видання наукових праць, методичної та навчальної літератури з питань школознавства, в яких розкривались напрямки діяльності директора школи, йогофункції та обов'язки. Зокрема, у 1941 році під редакцією Б. Бараша та А. Водковського виходить збірник статей, присвячених роботі директора та завуча шкоди, в яких описано підходи до організації внутрішкільного контролю та циклограма роботи директора [8].

3 початком активної фази військових дій у Другій світовій війні на території України у 1941 році припинилась будь-яка робота 3 підвищення кваліфікації працівників освіти, яку було відновлено лише після звільнення Києва від окупації у 1943 році.

Звісно, тривала перерва у підготовці освітян та військові дії призвели як до скорочення чисельності підготовлених працівників освіти, так і до зниження рівня їхньої професійної майстерності. У повоєнні роки було прийнято низку заходів щодо забезпечення закладів освіти кваліфікованими педагогічними працівниками. Зокрема, у 1947 році було затверджено «Положенння про методичну роботу у школі», 
«Положенння про районний педагогічний кабінет районного відділу народної освіти», «Положенння про кущове методичне об'єднання вчителів». Ці документи регламентували роботу всіх закладів підвищення кваліфікації вчителів, які тоді існували. Діяльність районних педагогічних кабінетів поступово відновлювалася. Ними систематично організовувались семінари для керівників та вчителів шкіл. Заняття проходили за тематикою, розробленою інститутом удосконалення вчителів [2]. Дия вирішення питання підвищення кваліфікації учителів усі педагогічні працівники, в тому числі й керівники шкіл з відповідною педагогічною освітою і стажем роботи не менше 15 років, мали один раз на 5 років проходити курсову підготовку. Для педпрацівників зі стажем роботи понад 15 років єдиною формою підвищення кваліфікації була самоосвіта.

У другій половині 40-х років стає зрозумілим, що в системі підвищення кваліфікації педагогів, в тому числі й керівників, назрівае низка проблемних питань, вирішення яких потребуе подальшого вдосконалення та розвитку системи післядипломної освіти педагогічних працівників. Це стосувалось насамперед iï уніфікації. 3 цією метою радянським урядом прийнято низку нормативних актів, серед яких у розрізі дослідження підвищення кваліфікації керівних кадрів слід відзначити постанову ЦККП(б)У від 3 грудня 1947 року «Про провадження єдиної системи підвищення кваліфікації вчителів та керівних кадрів». Відповідно до цього документа, у 1948 році введено в дію «Положення про єдину систему підвищення кваліфікації вчителів та працівників відділів народної освіти УРСР».

Початок 50 років став завершальним етапом переходу до загального обов'язкового семирічного навчання та запровадження загальної середньої освіти в стодицях республік, у містах республіканського значення, в обласних, крайових і найбільших промислових центрах. Поряд із цим, незважаючи на загальний розвиток післядипломної освіти педагогів, найменш охопленою цією роботою категорією працівників залишались директори шкіл та працівників органів управління освітою [1, с. 32].

Постановою Ради Міністрів і ЦК КП УРСР від 27 грудня 1952 р. 3 метою вдосконалення кваліфікації працівників органів управління освітою та посилення системи післядипломної педагогічної освіти було утворено Центральний інститут підвищення кваліфікації керівних працівників народної освіти Міністерства освіти Української РСР, що фактично ознаменував новий виток у становленні та розвитку системи післядипдомної освіти керівних педагогічних кадрів.

Висновки. Трансформаційні політичні та суспільні зміни, які відбувадись на теренах України, на початку XX сторіччя невпинно призведи до розвитку освітньої галузі, що зумовило розширення мережі закладів освіти. Зі збільшенням шкіл зростав кількісний склад педагогічних та учнівських колективів, що актуалізувало питання організації якісного та ефективного управління ними. У 30-х роках стає зрозумілим, що поліпшення навчання і виховання дітей неможливе без забезпечення закладів освіти професійними керівними педагогічними кадрами, які мають нести відповідадьність за організацію освітнього процесу. Проте низький рівень професійної підготовки педагогічних кадрів, а також відсутність наукового підходу до управдіння школою загострювали проблему необхідності наукових розробок із внутрішкільного управління та професійного зростання керівників шкіл. Наукове переосмислення в середині XX сторіччя провідної ролі ефективного управління закладом освіти та професіоналізму його керівника в організації освітнього процесу стає передумовою виокремлення із загальної системи післядипломної педагогічної освіти важдивої ії підсистеми, що мала на меті постійне професійне зростання керівних педагогічних кадрів. Організаційна структура цієї підсистеми може бути досліджена у подальших наукових пошуках. 


\section{Список використаних джерел:}

1. Гладуш В. А. Університет менеджменту освіти передісторія створення та розвитку. Вісник післядипломної освіти. Серія : Педагогічні науки. 2018. Вип. 1. С. 26-33.

2. Крисюк С. В. Становлення та розвиток післядипломної освіти педагогічних кадрів в Україні (1917-1995 рр.): автореф. дис... д-ра. пед. наук :13.00.01. Київ, 1996. 48 с.

3. Крисюк С. В. Становлення та розвиток післядипломної освіти педагогічних кадрів в Україні (1917-1941 рр.). Київ:УІПКККО, 1995. 174 с.

4. Мельникова А. С. Государственно-общественное управление образованием в системе повышения квалификации руководителей общеобразовательных учреждений: дисс. ... канд. пед. наук: 13.00.01. Москва, 2004. 180 с.

5. О начальной и среднейшколе: Постановление УК ВКП(б) 25 авг. 1931 г. Народное образование в СССР: Общеобразовательная школа: сборник документов 1917-1973 гг. Москва: Педагогика, 1974. C. $160-161$.

6. Пахомова Т. Г. Розвиток післядипломної освіти педагогічних працівників в Україні (20-30-ті роки XX століття): автореф. дис... канд. пед. наук: 13.00.01. Кіровоград, 2010. 20 с.

7. Постернак С. Із історії освітнього руху на Україні за часів революції 1917-1919 років. Київ, 1920. $128 \mathrm{c}$.

8. Работа директора и заведующегоучебнойчастьюшколы: Изопытаработы. Сборник статей / под ред. Б. А. Бараша и А. Н. Волковского. Москва: Учпедгиз, 1941. 207 с.

9. Сірополко С. Історія освіти в Україні: монографія. Київ: Наук.думка, 2001. 912 с.

10. Якухно I. I. Історико-педагогічні аспекти становлення та інноваційного розвитку післядипломної педагогічної освіти в Україні. Таврійський вісник освіти. 2011. № 1 (33). C. $5-19$.

\section{References:}

1. Hladush, V. A. (2018). Universytet menedzhmentu osvity peredistoriia stvorennia ta rozvytku [University of Education Management prehistory of creation and development]. Visnyk pisliadyplomnoi osvity. Seriia: Pedahohichni nauky, 1, 26-33 [in Ukrainian].

2. Krysiuk, S. V. (1996). Stanovlennia ta rozvytok pisliadyplomnoi osvity pedahohichnykh kadriv v Ukraini (1917-1995) [Formation and development of teachers' postgraduate education in Ukraine (1917-1995)]. (Extended abstract of Doctor's thesis). Kyiv [in Ukrainian].

3. Krysiuk, S. V. (1995). Stanolvlennia ta rozvytok pisliadyplomnoi osvity pedahohichnykh kadriv v Ukraini (1917-1941) [Formation and development of teachers' postgraduate education in Ukraine (1917-1941)]. Kyiv: UIPKKKO [in Ukrainian].

4. Melnikova, L. S. (2004). Gosudarstvenno-obshchestvennoe upravlenie obrazovaniem v sisteme povysheniia kvalifikatcii rukovoditelei obshcheobrazovatelnykh uchrezhdenii [State-public administration of education in the system of advanced professional training for heads of educational institutions]. (Candidate's thesis). Moskva [in Russian].

5. O nachalnoi i sredneishkole: Postanovlenie UK VKP(b) 25 avg. 1931 g. Narodnoe obrazovanie v SSSR: Obshcheobrazovatelnaia shkola: Sbornik dokumentov 1917-1973 [On primary and secondary school: Resolution of the Central Committee of the All-Union Communist Party (Bolsheviks) (dated August 25, 1931). Public education in the USSR: Secondary school: Collection of documents (1917-1973)]. Moskva: Pedagogika [in Russian].

6. Pakhomova, T. H. (2010). Rozvytok pisliadyplomnoi osvity pedahohichnykh pratsivnykiv v Ukraini (20-30-ti roky XX stolittia) [Development of pedagogical workers' postgraduate education in Ukraine (20s - 30s of the XX century)]. (Extended abstract of Candidate's thesis). Kirovohrad [in Ukrainian].

7. Posternak, S. (1920). Iz istorii osvitnoho rukhu na Ukraini za chasiv revoliutsii 1917-1919 rokiv [From the history of the educational movement in Ukraine during the revolution of 1917-1919]. Kyiv [in Ukrainian].

8. Barasha, B. L., \& Volkovskogo, A. N. (Ed.). (1941). Rabota direktora i zaveduiushchego uchebnoi chastiu shkoly: Iz opyta raboty. Sbornik statei [The work of the director and head of the educational part of the school: from work experience. Collected articles]. Moskva: Uchpedgiz [in Russian].

9. Siropolko, S. (2001). Istoriia osvity v Ukraini [History of education in Ukraine]. Kyiv: Nauk. dumka [in Ukrainian]. 
10. Yakukhno, I. I. (2011). Istoryko-pedahohichni aspekty stanovlennia ta innovatsiinoho rozvytku pisliadyplomnoi pedahohichnoi osvity $\mathrm{v}$ Ukraini [Historical and pedagogical aspects of formation and innovative development of postgraduate pedagogical education in Ukraine]. Tavriiskyi visnyk osvity, 1 (33), 5-19 [in Ukrainian].

\section{Vishnevskaya Ya. A., orcid.org/0000-0003-3703-4119 \\ RETROSPECTIVE ANALYSIS OF HISTORICAL AND PEDAGOGICAL PRECONDITIONS FOR THE DEVELOPMENT OF POSTGRADUATE EDUCATION OF LEADING PEDAGOGICAL STAFF OF UKRAINE}

The article examines the historical and pedagogical preconditions for the formation of the system of postgraduate education of heads of educational institutions in the first half of the twentieth century. In the context of successive transformations in the system of postgraduate pedagogical education, the peculiarities of the historical period of the first half of the twentieth century in which the formation of the national system of postgraduate pedagogical education took place are revealed. It is substantiated that the process of development of postgraduate education of leading pedagogical staff is inextricably linked with the development of the entire system of postgraduate pedagogical education, and is a consequence of historical awareness of the importance of effective management of educational institutions on the quality of educational process. On the example of censuses of educators conducted in 1929-1933, a description of the quantitative and qualitative composition of teachers was given, including the level of professional training of management teachers to manage educational institutions. The main forms of professional development of teachers in the first half of the twentieth century are described, among which as such, which was of special importance for the professional development of school principals, correspondence pedagogical education is singled out, describing the are as in which training was carried out. It is concluded that the question of the need for effective management of educational institutions arose as a reaction to the gradual political, social and cultural changes in Ukrainian society and the state, which deepened the problems of development of the entire educational sector. And scientific rethinking in the middle of the twentieth century of the leading role of effective management of educational institutions and professionalism of the head becomes a prerequisite for separation from the general system of postgraduate pedagogical education of its important subsystem, aimed at continuous professional growth of management teachers.

Key words: advanced training courses, managerial and pedagogical staff, course program, form and content.

Дата надходження статті: 07.052021 p. Рецензент: доктор педагогічних наук, професор Данилюк С. С.

У, ДК 378.1

DOI https://doi.org/10.37915/pa.vi49.284

Петренко Г. О.

orcid.org/0000-0002-5233-4219

\section{МУЗИЧНЕ ВИХОВАННЯ В УЧИТЕЛЬСЬКІХ СЕМІНАРІЯХ ПІВДНЯ УКРАЇНИ ДРУГОЇ ПОЯОВИНИ ХІХ - ПОЧАТКУ ХХ СТ. (НА ПРИКЛАДІ ХЕРСОНСЬКОЇ УЧИТЕЯЬСЬКОЇ СЕМІНАРІЇ)}

У статті аналізуеться проблема музичного виховання майбутніх педагогічних кадрів на Півдні України у другій половині XIX - на початку XX століття, розкриті передумови та історія виникнення учительських семінарій. Зазначено, що основним завданням цзих

*C Петренко Г. О.

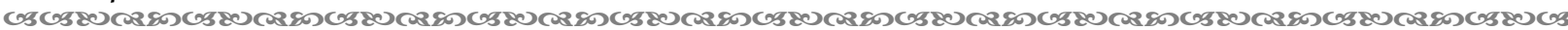
264 